\title{
ANTIMALARIAL POTENTIAL STUDY OF CUCUMBER SKIN AND BASE POINT CHLOROFORM EXTRACT AS A SOLUTION TO ORGANIC WASTE OF SIDEWALK FOOD STALL TREATMENT IN YOGYAKARTA
}

\author{
Imam Fathoni, Isnawan Ibnu Ikrandita, M. Dylan Lawrie, Eza Darisqi, \\ Gede Wahyu Mega Udayana, and Soenarwan Hery Poerwanto \\ Faculty of Biology, Universitas Gadjah Mada, Yogyakarta, Indonesia \\ Email : tonythoni@yahoo.com
}

\begin{abstract}
Malaria is a major infectious disease in the world. The disease is caused by blood protozoan from the genus Plasmodium. The main problem in controling this disease is resistance parasite cases to drugs that have been used. Cucumber (Cucumis sativa L.) contain bioactive compounds suspected of terpenoids and saponins are believed to reduce the level of parasitemia. Waste of skin and cucumber base is very abundant, especially from stalls in the city of Yogyakarta. Estimated at the base and cucumber skin there are bioactive content that can be used as an alternative antimalarial drug. This research aims to study the potential of chloroform extract and the base of the fruit peel waste to the level of parasitemia of Plasmodium berghei in mice.

First step is collecting the waste of skin and cucumber base in some stalls in the city of Yogyakarta. Extraction by maceration method using chloroform solvent, the method further phytochemical studies by Thin Layer Chromatography (TLC). Antiplasmodium test with negative control treatment (DMSO 0.3\%), positive control (chloroquine $3 \mathrm{mg} / \mathrm{kg}$ ), the dose C.sativa extract 100; 200; 300; 400 and $500 \mathrm{mg} / \mathrm{kg}$ in male mice given strain Switzerland 3 months of age infected with Plasmodium berghei orally.

$\mathrm{T}$ he results showed there were terpenoids and saponins compounds in the chloroform extracts of $C$.sativa base and skin. The most effective dose of the extract inhibition of parasitemia level P. berghei in mice treated P5 is the highest ( $500 \mathrm{mg} / \mathrm{kg} \mathrm{BB}$ ), which is still higher than the standard drug Chloroquine so that waste of skin and the base $C$.sativa potential as an alternative antimalarial drug.
\end{abstract}

Key words: Waste of skin and the base of cucumber (Cucumis sativa L.) Antimalarial.

\section{INTRODUCTION}

\section{Background}

Malaria is a major parasitic disease in the world. Malaria that caused by Plasmodium and transmitted by the Anopheles mosquito is a major disease in more than 100 countries and about 2.4 billion people threatened by this disease ( $40 \%$ of the world population). There are 3.3 billion people live in areas of potential malaria in 109 countries. In 2008 there were 190-311 million clinical cases and 708000-1003000 deaths in the world. Malaria also ranked as second in most infectious disease after HIV / AIDS (CDC, 2012). Over time there is resistance to the insecticide and drug resistance vectors against Plasmodium (Lohombo et al., 2004). The spread of resistant parasites to antimalarial drugs is so fast, wide and limited numbers led many researchers tried to discover new antimalarial compounds, the one of them are base point and skin of cucumber. Cucumber (Cucumis sativa L.) contain bioactive compounds suspected of terpenoids and saponins are believed to reduce the level of parasitemia. Waste of skin and cucumber base is very abundant, especially from stalls in the city of Yogyakarta. Estimated at the base and cucumber skin there are bioactive content that can be used as an alternative antimalarial drug. This research aims to study the potential of 
chloroform extract and the base of the fruit peel waste to the level of parasitemia of Plasmodium berghei in mice.

\section{MATERIALS AND METHODS}

\section{The equipment used in this study include:}

a. Weight measure Shimadzu LU-T 1200 series D, Weight measure AND GF 2000 series, vortex, Nouva II stir plate, magnetic stirrer

b. Closed vessel, knife cutting board, rote evaporator Heidolph VV 2000 SERIES, fan, heater.

c. Thin-layer chromatography instrument: capillary tube, double plate, vessel kromaografi, 254 and 65 UV lamps, hair dryer, pipettes, ovens, sprier bottle, fume hoods, camera, ORIT type VC-3310.

d. Tools glass: $500 \mathrm{ml}$ Erlenmeyer, $650 \mathrm{~mL}$ Erlenmeyer, flakon bottles, glass ukur10 mL, $100 \mathrm{~mL}$ measuring cylinder, separating funnel.

e. Treatment of test animals and making blood smear: Cages maintenance of mice, mice weight measure, analytical scales, vortex, syringe $2.5 \mathrm{ml}, 1 \mathrm{ml}$ sonde, Pasteur pipette, glass and cover glass objects, scissors, flakon tubes, and light microscopy

The main material is skin and the base of cucumber (C. sativa). Isolates of Plasmodium berghei ANKA strain. Mice (Mus musculus L.) male Swiss strain, 35 were caught. Organic solvents, namely acetone, chloroform, benzene wash, ethanol. Additional solvents namely: n-hexane, ethyl acetate, distilled water, ether and F254 silica plates. Spray reagent: cerium (IV) sulfate, iron (III) chloride (FeCl3), Dragendorff, ammonia vapor. Chemical reagents to make a thin blood smear preparations include: methanol, distilled water, a solution of Giemsa. DMSO solution of 3\% for the solvent extract.

\section{Skin and Base Cucumber Preparation}

a. Sample Collection

Samples of skin and the base of cucumber (C. sativa) was taken from several stalls in Yogyakarta. Sample collected for several days until accumulated quite a lot of waste is required. Samples are temporarily stored in the refrigerator to maintain freshness before sample extraction.

b. Extraction

Extraction was done by maseration method. The skin and the chopped base soaked by chloroform for 24 hours, then filtered. The extract's solvent evaporated. Chloroform and aquades added to the extract and divided by using funnel.

c. Thin Layer Chromatography (TLC)

A little amount of dried extract was taken then dissolved in chloroform. The stationary phase is silica gel F254 $2 \times 10 \mathrm{~cm}$ and the mobile phase is $\mathrm{n}$-hexane: ethyl acetate (3:1). After that, the extract solution spotted on a TLC plate using a capillary tube with a distance of $\pm 1 \mathrm{~cm}$ from the edge of the upper vessel. Eluent solution was placed on the petri disk and closed with the wider glass. While soaked, the vessel closed so the media not saturated by eluen solution. After the samples detected by UV light 
$254 \mathrm{~nm}$ and UV $365 \mathrm{~nm}$. Dye of cerium (IV) sulfate, ammonia vapor, iron (III) chloride, and Dragendorff sprayed on plate to reinforce the appearance that appear on the plate (Harborne, 1987).

\section{Preparation of mice}

As many as 35 Mice (Mus musculus L.) that used are from male Swiss strain within 23 months old with an average weight of 23-30 gram. Mice that used are the the breeding result of Integrated Research and Testing Laboratory (LPPT) UGM. Mice were treated on the environment, food, and drink the same water both qualitatively and quantitatively. A total of 21 mice were divided into 7 groups, each consisting of 3 mice with 2 details the control group and 5 treatment groups at random. Before being given treatment, mice were first isolated for 3 weeks and then treated for 4 days according to the method of Peter's Supressive Test (Peters, 1970).

\section{Administration of Plasmodium berghei and chloroform extracts of skin and cucumber base}

Treatment group and the control group of mice infected with P. bergheiby injecting 0.2 $\mathrm{ml}$ of blood containing $P$. berghei intraperitoneally. Treatment of giving the base of the fruit and skin extracts of cucumber (C. sativa) and $0.3 \%$ Tween started orally at $3 \mathrm{~h}$ after P. berghei infection.

\section{Manufacture of animal infection test inoculum}

a. Transfer of Plasmodium berghei

P.bergheiisolates were stored in liquid nitrogen $(-180 \circ \mathrm{C}$ temperature) then injected intraperitoneally at 3 donor mice and left for 1 week in order P. berghei reactive and stable.

b. Counting the number of erythrocytes

Number of erythrocytes was calculated by collecting $10 \mathrm{~mL}$ of blood from the mice's tail end by using micropipette and mixed with $990 \mathrm{~mL}$ RPMI medium homogeneously in tube-1. Then, $10 \mathrm{~mL}$ of the erythrocyte suspension transfered into tube-2 (dilution 104). The amount erythrocytes / $\mathrm{ml}$ calculated by haemocytometer method.

c. Calculation of population Plasmodium berghei / mL

The number of P. berghei/ $\mathrm{mL}$ was calculated to determine the exact number of $\mathrm{P}$. berghei in mice and to find out how many times dilution necessary to get the right dose of inoculum with $1 \times 107 \mathrm{P}$. berghei in $0.2 \mathrm{~mL}$. With the right dose, the difference between the number of infections one with another mice can be reduced and it is certain that the decline in parasitemia that occurred was the effect of treatment. Number of P. berghei / $\mathrm{mL}$ can be calculated by the following formula:

Number Plasmodium $/ \mathrm{mL}=$ percentage of parasitemia $\times$ number of erythrocytes $/ \mathrm{mL}$

d. Blood collection mice (Mus musculus L.) donor

Collection of mice blood that had been infected with P.berghei through cardiac puncture with injection syringe filled $0.1 \mathrm{mLACD}$. Mice that had took from the heart then killed using kloroform. Blood volume obtained from cardiac puncture then 
calculated to find out the amount of blood the heart $P$. bergheimultiplied by the number of mice with P. berghei/ $\mathrm{mL}$.

e. Production of inoculum

Animal infected with a dose of $1 \times 10^{7}$ P.berghei with $0.2 \mathrm{~mL}$ volume in each mouse showed the total amount of inoculum needed for 35 mice was $7 \mathrm{ml} \times 107 \mathrm{P}$. berghei. The inoculum can be obtained by heart puncture blood dilution with RPMI

\section{Test anti-plasmodium}

Antiplasmodium test was conducted by Peter's suppresive Test (Peters, 1970). In this test, mice treated group and the negative and positive control group were infected with P. berghei by injected $0.2 \mathrm{~mL}$ of blood containing $1 \times 10^{7} P$. berghei intraperitoneally. Treatment with bark extracts and cucumber base, $3 \% \mathrm{DMSO}$ and Chloroquine done orally for 4 consecutive days at a dose according to Table 2 .

Table 2. Patterns of treatment of the skin and the base of the chloroform extract of cucumber (C. sativa) against the Swiss strain mice Males

\begin{tabular}{|c|c|c|c|c|}
\hline Number & Group & Dose Treatment & $\begin{array}{l}\text { Solvent } \\
\text { Treatment } \\
\text { (DMSO 3\%) }\end{array}$ & $\begin{array}{l}\text { Treatment } \\
\text { (Infeksi } \\
10^{7} \text { P.berghei) }\end{array}$ \\
\hline 1 & $\mathrm{~K}(-)$ & - & + & - \\
\hline 2 & $\mathrm{~K}(+)$ & $\begin{array}{l}\text { Klorokuin } 3 \mathrm{mg} / \mathrm{kg} \\
\text { BB }\end{array}$ & - & + \\
\hline 3 & $\mathrm{P} 1$ & $100 \mathrm{mg} / \mathrm{kg} \mathrm{BB}$ & + & + \\
\hline 4 & $\mathrm{P} 2$ & $200 \mathrm{mg} / \mathrm{kg} \mathrm{BB}$ & + & + \\
\hline 5 & P3 & $300 \mathrm{mg} / \mathrm{kg} \mathrm{BB}$ & + & + \\
\hline 6 & $\mathrm{P} 4$ & $400 \mathrm{mg} / \mathrm{kg} \mathrm{BB}$ & + & + \\
\hline 7 & P5 & $500 \mathrm{mg} / \mathrm{kg} \mathrm{BB}$ & + & + \\
\hline
\end{tabular}

\section{RESULT AND DISCUSSION}

This study used 24 male mice (Mus musculus L.) strains SWISS aged 3 months that divided into two groups of negative controls, two positive control group, and five treatment groups. On the first day of the study, control and treatment group infected with blood containing Plasmodium berghei in intrapretoneal. Then, the extract given orally with various doses of the various treatments to compare the effectiveness with Chloroquine (standard drug). Extract dose used is 100;200;300; 400;500 mg / kg. Negative mice in group 2 were given the extract at a dose of $300 \mathrm{mg} / \mathrm{kg}$ BW to see the side effects of the extract to blood cells.

Every day each mouse in each group of blood drawn through the tail end of a blood thinner and made preparations for examination under a microscope parasitemianya level with 40x10 magnification.

Based on these images, there are difference between red blood cells infected with Plasmodium and normall cell. Red blood cells infected with Plasmodium appear to have reddish color. The core is a sign of Plasmodium-infected erythrocytes that enter the cell. This observation does not separate between tropozoit, merozoites, or schizon phase. Plasmodium infection cause lysis of infected erythrocytes. Parasitemia level examination results can be seen in the table 3 . 


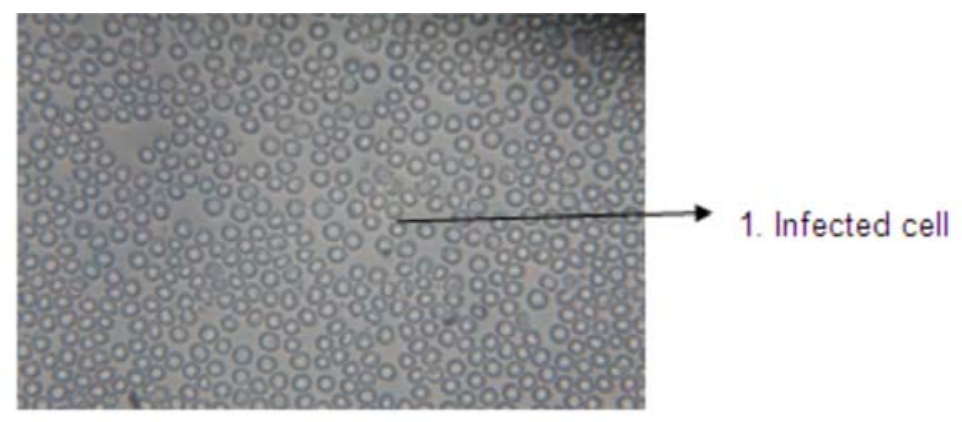

Figure 1. Infected red blood cells picture taken with DSLR camera

Table 3. The mean level of P.berghei parasitemia infected mice in the control group and the treatment given chloroform extract waste of skin and cucumber base

\begin{tabular}{llllll}
\hline & \multicolumn{5}{c}{ Research result } \\
\cline { 2 - 6 } Group & \multicolumn{1}{c}{$\mathbf{1}$} & $\mathbf{2}$ & $\mathbf{3}$ & $\mathbf{4}$ & $\mathbf{5}$ \\
\hline K(-) Ekstrak & 0 & 0 & 0 & 0 & 0 \\
K(-) Placebo & 0 & 0 & 0 & 0 & 0 \\
K(+) & $0,39 \pm 0,39^{(a)}$ & $2,84 \pm 3,45^{(a)}$ & $7,64 \pm 0,43^{(b)}$ & $7,44 \pm 0,23^{(\mathrm{d})}$ & $5,97 \pm 1,37^{(\mathrm{b})}$ \\
K(+) Kloroquin & $5,28 \pm 5,28^{(\mathrm{a}, \mathrm{b})}$ & $3,81 \pm 1,15^{(\mathrm{a})}$ & $3,99 \pm 0,37^{(\mathrm{a}, \mathrm{b})}$ & $4,16 \pm 0,41^{(\mathrm{c})}$ & $1,35 \pm 1,35^{(\mathrm{a})}$ \\
P1 (100 mg/kg BB) & $0,12 \pm 0,04^{(\mathrm{a})}$ & $4,96 \pm 3,25^{(\mathrm{a})}$ & $5,31 \pm 2,34^{(\mathrm{a})}$ & $3,88 \pm 0,52^{(\mathrm{c})}$ & $0,96 \pm 0,21^{(\mathrm{a})}$ \\
P2 (200 mg/kg BB) & $0,07 \pm 0,01^{(\mathrm{a})}$ & $4,89 \pm 0,51^{(\mathrm{a})}$ & $4,29 \pm 1,96^{(\mathrm{a}, \mathrm{b})}$ & $3,37 \pm 0,96^{(\mathrm{b}, \mathrm{c})}$ & $0,47 \pm 0,25^{(\mathrm{a})}$ \\
P3 (300 mg/kg BB) & $0,09 \pm 0,003^{(\mathrm{a})}$ & $3,05 \pm 1,38^{(\mathrm{a})}$ & $3,05 \pm 0,07^{(\mathrm{a})}$ & $2,14 \pm 0,35^{(\mathrm{a})}$ & $0,24 \pm 0,19^{(\mathrm{a})}$ \\
P4 (400 mg/kg BB) & $7,19 \pm 1,87^{(\mathrm{c})}$ & $6,33 \pm 0,64^{(\mathrm{a})}$ & $4,37 \pm 1,24^{(\mathrm{a}, \mathrm{b})}$ & $2,37 \pm 0,19^{(\mathrm{a}, \mathrm{b})}$ & $0,49 \pm 0,36^{(\mathrm{a})}$ \\
P5 (500 mg/kg BB) & $3,54 \pm 0,82^{(\mathrm{b})}$ & $4,97 \pm 2,85^{(\mathrm{a})}$ & $3,76 \pm 1,08^{(\mathrm{a}, \mathrm{b})}$ & $1,57 \pm 0,56^{(\mathrm{a})}$ & $0,51 \pm 0,3^{(\mathrm{a})}$ \\
\hline
\end{tabular}

Numer followed by same word in a column showing there's no significance difference (a-d)

ANOVA and DMRT test using SPSS 16.0 showed a significant difference between the positive control (untreated) with Chloroquine treatment and chloroform extracts of cucumber waste. This shows the inhibition effect of parasite growth by drugs. The data showed that there were significant difference between the drug Chloroquine with extract

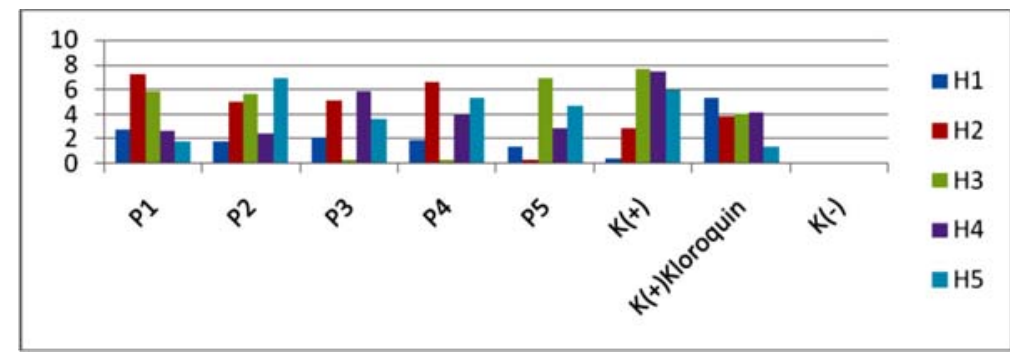

Figure 2. The mean level of P.berghei parasitemia infected mice in the control group and the treatment with chloroform extract dose variation cucumber waste

Based on the picture above, we can see the fluctuations in the mice parasitemia level. The most noticeable decline was shown by the P5 extract treatment doses $(500 \mathrm{mg} / \mathrm{kg})$ on fifth day. Overall, the rate of decline in the parasite by $C$.sativa extract treatment is better than the standard drug Chloroquine. This is due to the content of bioactive compounds such as alkaloids, flavonoids, terpenoids, and saponins in the extract. 


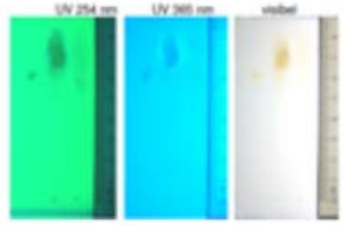

(a)

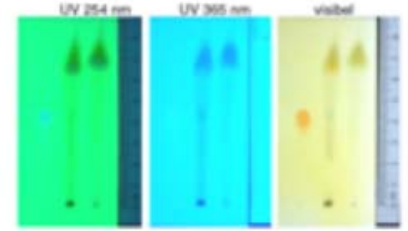

(b)

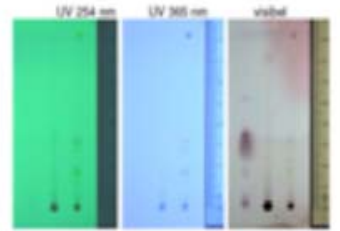

(c)

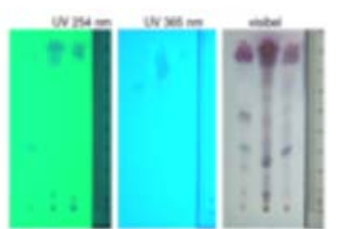

(d)

Figure 3. Results of bioactive compounds in the ethanolic extract C.sativa test (a) Alkaloid, (b) Flavonoid, (c) Terpenoid, (d) Saponin

Results of bioactive compounds test by thin-layer chromatography method showed that there are terpenoids and saponins as indicated by the formation of spots on the plate. The bioactive compounds work together to inhibit Plasmodium growth by interfering the synthesis of Plasmodium membrane. The compound will bind to the Plasmodium membrane components and cause the failure to replicate themselves.

Preparations of liver and kidney started after surgery on the fifth day to see the damage to the organ the treatment and non-treatment mice. based on observations at preserved organ, there is no damage to the liver and kidneys which showed chloroform extract of cucumbers did not cause adverse effects on organs and non-toxic.

\section{REFERENCES}

Anonim ${ }^{1}$. 2010. What is malaria?. http://www.malaria.org index.php?option=com. content \&task $=$ section\&id=8\&/temid $=32$

Anonim ${ }^{2}$. 2008. Indonesia masih menjadi negara endemis tinggi malaria. http: //www. pdpersi.co.id.

Anonim ${ }^{3}$. 2005. Parasite control. Nature Reviews/Immunology. Nature Publishing Group. CDC. 2012.Malaria.http://www.cdc.gov/malaria/

Finney, D.J. 1971. Analysis Probit. 3th edition.Cambridge University Press. Britain.

Fujioka, H., and M. Aikawa. 2002. Structure and life cycle. http://www.online.karger.com/ ProdukteDB/Katalogteile/isbn3_8055/73/76/Cl8Fujioka

Food Composition Table for Use in East Asia.1972. US Departement of Health, Education and Welfare, FDA UN,

Harborne, J.B. 1987. Phytochemical Methods: A Guide to Modern Techniques of Plant Analysis. Chapman \& Hall Inc. London

Herbert, R.B. 1995. Biosintesis metabolit sekunder. Diterjemahkan oleh Bambang Srigandono. Semarang: IKIP Semarang Press.

Janse, C., and A. Waters. 2007. The Plasmodium berghei research model of malaria. www.lumc.nl/ 1040/research/malaria.model05.html.

Khomsan, A. 2009. Rahasia Sehat Dengan Makanan Berkhasiat. Penerbit Buku Kompas. Jakarta.

Levine, N.D. 1995. Protozoologi veteriner. Gadjah Mada University Press.Yogyakarta

Lohombo-Ekomba. 2004. Antibacterial, antifungal, antiplasmodial and cytotoxic activities of Albertisia villosa. Journal of ethnopharmacy. 93 (2004) 331-335.

Peter, Y. 1970. Technique for study of drug response in experimental malaria chemotherapy and drug resistance in malaria. New York: Academic Press.

Smyth, J.D. 1994. Introduction to Animal Parasitology. Third Edition. Cambridge University Press.Cambridge. 